Cornell Law Library

Scholarship@Cornell Law: A Digital Repository

Cornell Law Faculty Publications

Faculty Scholarship

$6-2002$

\title{
Rights Inside Out: The Case of the Women's Human Rights Campaign
}

Annelise Riles

Cornell Law School, ar254@cornell.edu

Follow this and additional works at: http://scholarship.law.cornell.edu/facpub

Part of the Human Rights Law Commons, and the Women Commons

\section{Recommended Citation}

Riles, Annelise, "Rights Inside Out: The Case of the Women's Human Rights Campaign" (2002). Cornell Law Faculty Publications. Paper 1035.

http://scholarship.law.cornell.edu/facpub/1035

This Article is brought to you for free and open access by the Faculty Scholarship at Scholarship@Cornell Law: A Digital Repository. It has been accepted for inclusion in Cornell Law Faculty Publications by an authorized administrator of Scholarship@Cornell Law: A Digital Repository. For more information, please contact jmp8@cornell.edu. 


\title{
ARTICLES
}

\section{Rights Inside Out: The Case of the Women's Human Rights Campaign}

\author{
Annelise Riles*
}

Keywords: women's rights; human rights; activism; academics; networks.

\begin{abstract}
This essay traces the relationship between activists and academics involved in the campaign for "women's rights as human rights" as a case study of the relationship between different classes of what I call "knowledge professionals" self-consciously acting in a transnational domain. The puzzle that animates this essay is the following: how was it that at the very moment at which a critique of "rights" and a reimagination of rights as "rights talk" proved to be such fertile ground for academic scholarship did the same "rights" prove to be an equally fertile ground for activist networking and lobbying activities? The paper answers this question with respect to the work of self-reflexivity in creating a "virtual sociality of rights."
\end{abstract}

\section{INTRODUCTION}

It is 5 September 1995, mid-way through the staid and laborious proceedings of the United Nations Fourth World Conference on Women in Beijing. The delegates' seats, usually filled only with a handful of bureaucrats who nap or doodle through the ministerial speeches, are suddenly brimming with anticipation as Hillary Rodham Clinton takes the podium to thunderous applause. In marked contrast to the speeches delivered to that point, Clinton's is a political speech in the North American style, and it hits its target with the delegates assembled in this room as with the activists at the non-governmental organization ('NGO') meeting watching by close-circuit television as each paragraph elicits cheers and applause:

I believe that, on the eve of a new millennium, it is time to break our silence. It is time for us to say here in Beijing, and the world to hear, that it is no longer acceptable to discuss women's rights as separate from human rights. [...] It is a

* Visiting Professor, Yale Law School

I am grateful to Bryant Garth, David Kennedy, Hirokazu Miyazaki, Kunal Parker, Lisa Pruitt, Doug Cassel, Karen Knop, Ed Morgan, Eve Darian-Smith, the participants in the faculty workshop, University of California, at Davis School of Law, and the Human Rights Workshop, Yale Law School, where this paper was presented, and to Beth Olds for research assistance. Funding for ethnographic research and writing was generously provided by the American Bar Foundation, the Howard Foundation, the American Council of Learned Societies, the National Endowment for the Humanities, the Social Science Research Council, the Cambridge Commonwealth, Livingstone and Overseas Trusts and Trinity College, University of Cambridge. 
violation of human rights when babies are denied food, or drowned, or suffocated, or their spines broken, simply because they are girls.

It is a violation of human rights when women and girls are sold into the slavery of prostitution.

It is a violation of human rights when women are doused with gasoline, set on fire and burned to death because their marriage dowries are deemed too small.

It is a violation of human rights when individual women are raped in their own communities and when thousands of women are subjected to rape as a tactic or prize of war.

It is a violation of human rights when a leading cause of death worldwide among women ages 14 to 44 is the violence they are subjected to in their own homes.

It is a violation of human rights when young girls are brutalized by the painful and degrading practice of genital mutilation.

It is a violation of human rights when women are denied the right to plan their own families, and that includes being forced to have abortions or being sterilized against their will.

If there is one message that echoes forth from this conference, it is that human rights are women's rights [...]. And women's rights are human rights. ${ }^{1}$

From the point of view of the delegates assembled in the audience, the speech was courageous and path breaking in its demand for action; indeed it was action. ${ }^{2}$ (That afternoon, the young program officer for the Fiji Women's Rights Movement, with whom I have come to Beijing, and who had always displayed a good deal of cynicism about US interests in the Pacific exclaimed to me, "you must be so proud to be an American today!") Yet the audience for Clinton's speech was as much her political enemies in Washington who had denounced her attendance at this meeting ${ }^{3}$ as the delegates assembled in Beijing, and she addressed these critics quite explicitly. Indeed, one can read her speech as much as a defense of UN conferences as a defense of women's human rights. ${ }^{4}$ The human rights

1. H.R. Clinton, Statement at the United Nations Fourth World Conference on Women, Beijing, China (5 September 1995), at gopher://gopher.undp.org/00/unconfs/women/conf/gov/ 950905175653 (emphasis added).

2. Cf. A. Riles, The Network Inside Out (2000).

3. See, e.g., C. Bogert, Women in China: 'We Turned this Around', Newsweek, 18 September 1995, at 50; BBC Summary of World Broadcasts, Hillary Clinton's "improper" speech contained "nonsensical and preposterous arguments," Monday, 18 September 1995, Part 3, Asia-Pacific, UN Fourth World Conference on Women; EE/D2411/S2. (Zhongguo Tongxun She news agency, Hong Kong, in Chinese, 16 September 1995).

4. See Clinton, supra note 1:

There are some who question the reason for this conference. Let them listen to the voices of women in their homes, neighborhoods, and workplaces. There are some who wonder whether the lives of women and girls matter to economic and political progress around the globe [...]. Let them look at the women gathered here and at Huairou [...] the homemakers, nurses, teachers, lawyers, policymakers, and women who run their own businesses.

It is conferences like this that compel governments and peoples everywhere to listen, look and face the world's most pressing problems.

Wasn't it after the women's conference in Nairobi ten years ago that the world focused for the first time on the crisis of domestic violence? 
message seemed to strike just the right note, in the context of Washington politics, to put her critics on the defensive. At the same time, the slogan included nothing to generate a controversial sound bite on that evening's news broadcast.

The speech also anticipated another audience. As Clinton's speechwriters would have understood, for several years prior to the Beijing Conference, a coalition of organizations had spearheaded a campaign around these precise words. ${ }^{5}$ At issue were several related goals. The first was to gain new purchase for feminist concerns by associating these with the powerful language of human rights. The second was to gain acceptance for so-called 'second and third generation' human rights - rights that extend beyond the political and civil rights of the Cold War era ${ }^{6}$ which proponents imagined only governments to owe to their citizens, from the right to development to the recognition of violence between private parties, as a human rights violation by associating these with the popular cause of women's rights. ${ }^{7}$ The strategy, then, was to understand these two goals and these two domains - human rights and feminism - as versions of one another so that each might take hold through an engagement with the other. $^{8}$

The 'women's rights are human rights' strategy has a long and distinguished pedigree and one of great importance to its practitioners. From the inception of the UN Commission on the Status of Women in 1946, the establishment women's rights groups that followed its proceedings as official observers lobbied for women's political rights and the legal rights of married women. ${ }^{9}$ However, the 'second generation' of women's rights NGOs which became active at the United Nations during the UN Decade for Women (1975-1985) self-consciously emphasized a new and broader

5. See, e.g., C. Bunch, Organizing for Women's Human Rights Globally, in J. Kerr (Ed.), Ours by Right: Women's Rights as Human Rights 141 (1993).

6. See Y. Dezalay \& B. Garth, The Internationalization of Palace Wars: Lawyers, Economists and the Contest to Transform Latin American States (2002).

7. See C. Bunch \& S. Frost, Human Rights, in C. Kramarae \& D. Spender (Eds.), Routledge International Encyclopedia of Women: Global Women's Issues and Knowledge 1078 (2000); R. Cook, Women's International Human Rights Law: The Way Forward, in R. Cook (Ed.), Human Rights of Women: National and International Perspectives 3 (1994).

8. Of course 'first generation' human rights only appear as a stable, settled category from the point of view of the campaign to expand the category. As described in the final section of this article, the category becomes real only through an engagement with the 'outside.' For a discussion of the conflicts over the status of first generation human rights at the UN, the terms of which structurally mirror the material presented in this essay, see F.D. Gaer, Reality Check: Human Rights NGOs Confront Governments at the UN, in T.G. Weiss \& L. Gordenker (Eds.), NGOs, the UN, and Global Governance 51 (1996).

9. See J. Connors, NGOs and the Human Rights of Women at the United Nations, in P. Willetts (Ed.), The Conscience of the World: The Influence of Non-Governmental Organizations in the UN System 147, at 154 (1996). See M.E. Galey, Women Find a Place, in A. Winslow (Ed.), Women, Politics and the United Nations 11 (1995) for a discussion of the history of the Commission on the Status of Women and of the NGOs that participated in its activities. 
slate of 'issues,' from peace to domestic violence to nutrition. ${ }^{10}$ What is new, then, about the latest turn to 'rights' is the attempt to recast some of these second generation 'issues' (most notably violence against women) as a matter of "rights. ${ }^{11}$

What is also new about the recent return to rights is the lack of contention over this agenda. While the project met with some initial skepticism from activists in the developing world, that skepticism has not taken the form of any concerted organization against it. This is in marked contrast to the bruising conflicts among 'First' and 'Third World' feminists in the 1970s and 1980s over the direction of the global women's movement. ${ }^{12}$ Indeed, this essay must be read as an account of a campaign that by 1995 had largely succeeded. ${ }^{13}$ Human Rights Watch, for example, notes that governments, donors and NGOs now at least must nominally recognize that women's rights issues fall within the purview of human rights. ${ }^{14}$ The campaign's organizers illustrate this success most often with reference to the language of the documents negotiated at recent UN world conferences, including especially the World Conference on Human Rights held in Vienna in 1993 and the UN Fourth World Conference on Women. ${ }^{15}$ This newfound unity around rights may strike academic readers as surprising given the vigorous critique of rights and of universalism more broadly that permeated legal scholarship during exactly the same period.

10. See Connors, id.

11. E. Reichert, Women's Rights are Human Rights: Platform for Action, 413 Int'l Soc. Work 371 (1998).

12. See A.S. Fraser, The UN Decade for Women: Documents and Dialogue (1987); see also M.E. Keck \& K. Sikkink, Activists Beyond Borders: Advocacy Networks in International Politics, at 177 (1998) (quoting activist Charlotte Bunch as explaining that violence as a human rights issue was selected largely to overcome North-South divisions in the global women's movement).

13. As described further later, the campaign defined its goal as to insure that women's rights became an accepted part of the mainstream human rights agenda.

14. $C f$. E.H. Boyle \& S.E. Preves, Sovereign Autonomy Versus Universal Human Rights: The Bases for National Anti-Female-Genital Excision Laws (1998) (unpublished manuscript); Keck \& Sikkink, supra note 12; see also Human Rights Watch, Human Rights Watch World Report 1999: Women's Human Rights (1999), available at www.hrw.org (noting that "one concrete example of this rhetorical success is the inclusion of rape, sexual slavery, enforced prostitution, forced pregnancy, and enforced sterilization as war crimes and crimes against humanity" in the 1998 Treaty of Rome for the creation of an International Criminal Court new world criminal court).

15. See, e.g., Bunch \& Frost, supra note 7. See also United Nations Fourth World Conference on Women, Beijing Declaration, in Report on the Fourth World Conference on Women, UN Doc. A/Conf.177/20 (17 October 1995) (explicitly referring to women's human rights several times (e.g., paras. 8 and 9) and also directly asserting that "Women's rights are human rights" (para. 14)). See D. Otto, Rethinking the 'Universality' of Human Rights Law, 29 Colum. Human Rts. L. Rev. 1, at 128 (1997), for a more recent critique of the limitations of the 'women's rights as human rights' strategy. Dianne Otto points out there is no discussion of 'rights' at all in the sections of the Beijing Platform for Action devoted to poverty and economic structures, and that this suggests that the campaign has succeeded more in including women in the existing human rights framework than in transforming or expanding the category of human rights itself. 
During the period I describe in this paper, then, rights emerged as the focal point of both an intensive self-reflexive feminist critique and a flurry of activist 'networking.'

As an anthropologist, as well as a very minor participant in the events described here, my aim is not to contribute to the arguments for or against women's rights as human rights per se, nor is it to offer a defense or critique of the movement - all of these projects have already been performed better than I could hope to do. Rather, my interest in the constellation of academic debates, people, ideas, conferences and institutions associated with 'women's human rights' circa 1995 is in understanding how causes like 'women's rights as human rights' are made, and what kinds of institutions, professionals and further causes they make in turn. In recent years, anthropologists have begun to address the special problems of research into the character of late modern institutions and the knowledge they produce. Science Studies scholars have learned much about the micro-sociology of institutions within which the givens of scientific knowledge are constructed, ${ }^{16}$ and others have pursued parallel insights into the character of bureaucracies, ${ }^{17}$ of professionalism, ${ }^{18}$ and even of the academy. ${ }^{19}$ One theme emerging from this work concerns the articulation, appropriation and circulation of academic or artistic knowledge in commercial, bureaucratic and professional contexts. ${ }^{20}$ In this essay, I am interested in extending this project to an understanding of the work of what I call legal knowledge professionals - academics, bureaucrats, activists selfconsciously acting in a transnational and legal domain. ${ }^{21}$ I take the 'women's rights are human rights' campaign and the activities of so-called

16. See, e.g., D. Haraway, Primate Visions: Gender, Race, and Nature in the World of Modern Science (1992).

17. See, e.g., M. Herzfeld, The Social Production of Indifference: Exploring the Symbolic Roots of Western Bureaucracy (1992).

18. See, e.g., A. Mol, Missing Links, Making Links: The Performance of Some Atheroscleroses, in M. Berg \& A. Mol (Eds.), Differences in Medicine: Unraveling Practices, Techniques, and Bodies 144 (1998).

19. See, e.g., T.S. Kuhn, The Structure of Scientific Revolutions (1996); P. Bourdieu, Homo Academicus (1988); M. Strathern, Partial Connections (1991); B. Reading, The University in Ruins (1996).

20. See, e.g., D. Brenneis, New Lexicon, Old Language: Negotiating the 'Global' at the National Science Foundation, in G. Marcus (Ed.), Critical Anthropology Now: Unexpected Contexts, Shifting Constituencies, Changing Agendas 123 (1999); G. Born, Rationalizing Culture: IRCAM, Boulez, and the Institutionalization of the Musical Avant-Garde (1995); G.E. Marcus \& F.R. Myers, The Traffic in Art and Culture: An Introduction, in G.E. Marcus \& F.R. Myers (Eds.), The Traffic in Culture: Refiguring Art and Anthropology 1 (1995); B. Latour, Drawing Things Together, in M. Lynch \& S. Woolgar (Eds.), Representation in Scientific Practice 19 (1990); P. Rabinow, French Modern: Norms and Forms of the Social Environment (1989); Y. Dezalay \& B. Garth, Dealing in Virtue: International Commercial Arbitration and the Construction of a Transnational Legal Order (1996); J. Radway, A Feeling for Books: The Book-of-the-Month Club, Literary Taste, and Middle-Class Desire (1997); Riles, supra note 2.

21. See A. Riles, The Transnational Appeal of Formalism: The Case of Japan's Netting Law, at http://www.SSRN.com. 
'women's NGOs' more generally as one sphere for such an inquiry. The objective, in other words, is a better understanding of how knowledge practices are shared and not shared between different classes of professionals self-consciously acting in a transnational legal domain.

To academics, it is largely self-evident that academic and activist knowledge practices are worlds apart. In fact, the distance between academic and bureaucratic or activist knowledge has often served as a useful grounding for analysis - a means of reflecting, for example, on the character of academic thought through the lens of comparison. ${ }^{22}$ The divide seems equally real for the activist community in a different sense: academics and their insights hardly figure explicitly in activist networks at all. Offhand comments by activists about the privileged access of academics to UN bureaucrats ${ }^{23}$ or about mutual misunderstandings, ${ }^{24}$ offer some evidence of overt tensions. ${ }^{25}$ Perhaps, then, academics and practitioners are as distant from one another as anthropologists once took 'Western' and 'non-Western' knowledge practices to be. Perhaps we should be wary of assuming that what motivates 'them' is transparent to 'our' analysis.

Yet the critiques of the West/non-West divide in anthropology ${ }^{26}$ as in human rights might lead us to conclude that perhaps this concern is misplaced: how do we come to terms with the 'overlap' between 'communities' (a wholly unsatisfactory metaphor) as when sociologists serve as 'consultants' to human rights organizations or law professors become bureaucrats? Or how do we theorize alternating motivations - the feminist legal scholar's self-understanding as both theorist and activist, for example? Indeed, in practice there is such continual contact between the two camps that it is impossible to define either with any clarity: an academic pitched recent theory to activists by telling them why they should care about the dominance of the state in human rights law for example ${ }^{27}$ or a key organizational player in the women's human rights campaign co-

22. See, e.g., D. Kennedy, Spring Break, 63 Tex. L. Rev. 1377 (1985).

23. See, e.g., B. Adams, The UN, World Conferences and Women's Rights, in J. Kerr (Ed.), Ours by Right: Women's Rights as Human Rights 115, at 117 (1993).

24. See, e.g., Cook, supra note 7, at 31.

25. See, e.g., id. Cook concludes her summary of the proceedings of a "consultation of lawyers" on women's human rights with the comment that:

The consultation showed that among lawyers there must be better interaction in the work of theoreticians and practitioners. Academic lawyers working on the integration of women's human rights into the universal human rights movement must be aware of how theoretical concepts depend for effectiveness on applicability according to the rules of practice and needs of documentation of human rights committees, courts, and commissions. Legal practitioners must recognize that their work will be enriched by awareness of feminist analysis, and the relation of practical goals to the transcending evolution of the human rights movement.

26. See, e.g., N. Thomas, Entangled Objects: Exchange, Material Culture, and Colonialism in the Pacific (1991).

27. See K. Knop, Why Rethinking the Sovereign State is Important for Women's International Human Rights Law, in Cook, supra note 7, at 153. 
sponsored panel discussions at the World Summit on Social Development with a network of academic women from the South. One might also note activists' frequent use of academics' statistical studies in their campaigns and publications. There were even post-structuralist arguments by young employees of NGOs produced to dispute claims about the cultural specificity of human rights. ${ }^{28}$ Some of the most interesting evidence of crossfertilization was a genre of advocacy that took the form of historical ${ }^{29}$ or sociological ${ }^{30}$ studies of the women's human rights movement itself. This leads us to the question of reflexivity. Simply put, how am I to make human rights accessible, in sociological terms, given that the issues are as much 'mine' (the academic's) as 'theirs' (the activist's, the bureaucrat's)? No longer is it possible to debunk one discourse in terms of another - to apply one set of tools (academic, for example) to uncover the truth about the other knowledge practices (activist, for example). The relationship between academics and activists also presents a problem of ethnographic description. Some scholars and activists know one another personally while many do not. There are periodic conferences at which an always slightly different list of participants assembles. Volumes of articles are produced; speeches are made and circulated - read or filed away. It is difficult, in other words, to describe any singular 'community' that might be the subject of ethnographic inquiry here. In my previous work on international institutions, I have handled this dilemma by creating a certain synthetic distance between my own knowledge practices and those of my subjects. I have done so by turning away from the 'message' or 'issues' ('women's rights are human rights,' for example) to focus instead on matters of 'form' in institutional practices. ${ }^{31}$ However, in the hands of the social scientist, this synthetic distance can easily be taken for a 'real' one. I raise this issue in response to a debate concerning whether socio-legal studies might have something to contribute in return to the disciplines from which it has borrowed so heavily over past decades.

As we will see, the 'problem' of reflexivity was a question with profound effects circa 1995 on both scholarship and activism. 'Reflexivity' is not just a matter of methodology however: it also has a sociology. How 'issues' become rights - real and independent of the analysis - and then how these rights in turn become the subject of self-reflexive analysis - is one means of bringing that sociology into view. The challenge, then, is to understand the 'reflexive turn' as both a methodological question and something to be observed.

28. See, e.g., A. Rao, The Politics of Gender and Culture in International Human Rights Discourse, in J. Peters \& A. Wolper (Eds.), Women's Rights, Human Rights: International Feminist Perspectives 167 (1995).

29. See, e.g., Bunch \& Frost, supra note 7.

30. See E. Friedman, Women's Human Rights: The Emergence of a Movement, in Peters \& Wolper, supra note 28 , at 18.

31. See A. Riles, Infinity Within the Brackets, 25 Am. Ethnologist 378 (1998); Riles, supra note 2. 
The puzzle that animates this essay is the following: how was it that at the very moment at which a critique of 'rights' 32 and a reimagination of rights as 'rights talk" ${ }^{33}$ had proved to be such a fertile ground for academic scholarship did the same 'rights' prove to be an equally fertile ground for activist networking and lobbying activities? I begin with the following hypothesis about this activity: human rights 'action' among both academics and activists circa 1995 occurred in two genres. The first I will call 'human rights as project' and the second 'human rights as representation.'

\section{Human Rights as Project}

Those of us with the opportunity to be here have the responsibility to speak for those who could not. ${ }^{34}$

In 1995, the women's human rights campaign was one of the most important activities of the handful of NGOs whose niche is advocacy for women on the 'international level.' The Center for Global Women's Leadership ('CGWL') at the University of Rutgers, founded in 1989 with the goal of relating women, human rights and violence issues, is often credited for organizing the campaign. ${ }^{35}$ Other organizations at the center of the campaign included the International Women's Tribune Center ('IWTC'), an organization founded after the first UN conference on women held in Mexico City in 1975 and located across the street from the UN headquarters in New York, and the Women's Environment and Development Organization ('WEDO') also based within a stone's throw of the United Nations in New York. Although these organizations were based in the United States ${ }^{36}$ their target was the United Nations' version of the global. Activities centered on UN processes, conferences and documents, and in this the human rights campaign was no exception.

Each of these organizations was associated with the personality of one figure at its helm. The Director of CGWL was a lawyer and professor of women's studies Charlotte Bunch. Anne Walker, a former YWCA employee who holds a Ph.D. in communications, was the founder and Director of IWTC. Former New York congresswoman Bella Abzug was the co-founder and President of WEDO. These leaders were senior, seasoned women's rights activists with the management level contacts at UN agencies and at the major funding agencies necessary to survive in the highly competitive world of human rights activism. They had worked closely with one another for many years. Most were veterans of the 'second wave' feminist

32. See, e.g., R.M. Unger, The Critical Legal Studies Movement (1983).

33. See, e.g., M.A. Glendon, Rights Talk: The Impoverishment of Political Discourse (1991).

34. Clinton, supra note 1.

35. See, e.g., Keck \& Sikkink, supra note 12 , at 184.

36. One exception is the International YWCA which is based in Geneva. 
movement of the 1960s and 1970s in the United States and overseas and had been involved in UN activities since the UN First World Conference on Women, held in 1975. Periodic criticisms of Euro-American bias were also addressed by assembling a geographically and racially diverse staff and board of directors or by involving equally seasoned women's rights activists from different regions of the world in periodic strategy meetings. In sum, the leadership of the 'movement' consisted of a small and tight circle. I will refer to these organizations as 'global women's organizations' in order to capture their own understanding of the character of their mission.

Of course in order for the global women's organizations to garner funding for their campaigns 'women's rights as human rights' had to have already crystallized as an 'issue' - something that might be funded - in the minds of donors. ${ }^{37}$ It is at this point that the conversation among activists, bureaucrats and academics was relevant from activists' point of view. Contemporaneous with the activities described above, a growing academic literature, curriculum and conference agenda began to appear on the question of 'women's human rights.'

The central agents of these other, academic kinds of projects were international lawyers who served as experts on consultant bodies and national governments, made speeches at the United Nations, served as experts in the media and gave lectures at activist conferences. These academic practitioners shared with the global women's organizations an interest in influencing UN processes to gain acceptance and enforcement of 'women's rights as human rights' and a detailed knowledge of UN procedures and actors - the implications of different theories of government accountability in human rights law, the possible uses of reporting systems under the various relevant treaties, the institutional politics of UN bodies. ${ }^{38}$ This work was not the limited province of law professors, however: there were research "projects" as well as bureaucratic and legal projects. Political scientists served as "gender" consultants to UN bodies, ${ }^{39}$ anthropologists "documented" instances of bride-burning, and some academics even took

37. Cf. Riles, supra note 2 .

38. See Cook, supra note 7; R. Cook, State Accountability Under the Convention on the Elimination of All Forms of Discrimination Against Women, in Cook, supra note 7, at 228; cf. M. Rishmawi, The Developing Approaches of the International Commission of Jurists to Women's Human Rights, in Cook, id., at 340; J. Fitzpatrick, The Use of International Human Rights Norms to Combat Violence Against Women, in Cook, id., at 532.

39. For example, a key UN document for the Beijing Conference - the Secretary-General's mandated report on "existing technical and financial programmes in favor of women" - was prepared by an academic "consultant" described in the report as an "expert in gender and organizational behaviour." The Report is peppered with political science terminology and citations. See United Nations Economic and Social Council, Commission on the Status of Women, Preparations for the Fourth World Conference on Women: Actions for Equality, Development and Peace: Technical Assistance and Women: From Mainstreaming Towards Institutional Accountability, UN Doc. E/CN.6/1995/6 (19 December 1994). 
as their own activist project the task of sparring with their less projectoriented colleagues over their failure to engage with rights as a project. ${ }^{40}$

Activities for the 'women's rights are human rights' campaign included a global petition drive calling on the inclusion of women's rights in the agenda for the UN World Conference on Human Rights held in Vienna in 1993, panels and seminars at UN conferences in 1993, 1994 and 1995, much lobbying within the UN bureaucracy and among national bureaucracies, and the publication of newspaper and academic articles. ${ }^{41}$ The concrete goal of the campaign was simply to have the phrase 'women's rights are human rights' appear as prominently as possible in as many UN documents as possible. The women's human rights campaign focused primarily on the example of violence against women, as Bunch and colleagues explained:

Prior to the Vienna conference, the Global Campaign made a strategic decision to emphasize issues of gender-based violence since they illustrate best how traditional human rights concepts and practice are gender-based and exclude a large spectrum of women's experience of abuse. ${ }^{42}$

In interviews, however, Bunch has suggested that her interest in violence predated her interest in human rights by several years ${ }^{43}$ - that the turn to human rights was a strategic means of foregrounding of the issue of violence among many possible feminist causes rather than a means of promoting the concept of women's rights as human rights. As we will see, this ambivalence over whether human rights was a tool to a greater end, or a final end in itself pervaded the campaign's agenda and self image.

40. Consider, for example, the way the following conclusion to a recent review article on anthropology and human rights takes academics to task for their "relativism" on human rights questions:

Over the last 45 years, the world, the discipline of anthropology, and the human rights framework have changed. [...] Anthropologists since 1947 have moved from criticizing universal human rights [...] and are now expanding the scope, filling in the content, and participating in organizations for the enforcement of these rights. The mid-century anthropologists struggled with questions of cultural relativism mostly as a debate over cultural values $[\ldots]$, but changing world conditions, the clear violations of human decency and dignity on the part of non-Western political leadership under the banner of cultural relativism, as well as the expansion of the human rights concept - to incorporate people's rights, a range of socioeconomic rights, the rights of indigenous peoples, and the rights to development (as defined by Third and Fourth World peoples) - have all changed the human rights problematique and correspondingly anthropologists' responses to it.

See E. Messer, Anthropology and Human Rights, 22 Ann. Rev. Anthropology 221, at 240 (1993).

41. The most celebrated of these is C. Bunch, Women's Right's as Human Rights: Toward a Revision of Human Rights, 12 Hum. Rts. Q. 486 (1990).

42. C. Bunch, S. Frost \& N. Reilly, Making the Global Local: International Networking for Women's Human Rights, in K.D. Askin \& D.M. Koenig (Eds.), Women and International Human Rights Law, Vol. 1, 91, at 95 (1999).

43. See Keck \& Sikkink, supra note 12. 
It is important to note that even among the group of insiders assembled by the CGWL for the purpose of developing the campaign's strategy there were doubts at the outset about this campaign. ${ }^{44}$ The movements' cosmopolitan appreciation of others' confusion and even disagreement over the campaign figured prominently in their actions.

The high point of the campaign for 'women's rights as human rights' is said to be the UN World Conference on Human Rights held in Vienna in $1993 .{ }^{45}$ At that Conference, the global women's organizations successfully lobbied delegates to adopt the slogan as one of the Conference's central themes. ${ }^{46}$ The UN conferences that followed - the World Summit on Development held in Copenhagen in 1994 and the UN Fourth World Conference on Women held in Beijing in 1995 - were something of a disappointment in contrast as it proved impossible to secure statements that rights to development are human rights at the former, and the 'opposition' was a far more organized opposition at the latter. ${ }^{47}$ Indeed, one of the most interesting twists in the blockage of the global women's organizations at the Beijing Conference was the Vatican's own adoption of 'universal human rights' as its rallying cry against the inclusion of language supporting reproductive rights. For the campaign, therefore, a high point of the Beijing Conference was Hillary Clinton's metered, purposeful repetition of the slogan. This was the project: the repetition of a phrase in the documents as in the conference hall. What defined the project mode of thinking about human rights, in contrast to the alternative to be dis-

44. Bunch, Frost \& Reilly, supra note 42, at 97. ("Some women were concerned that the focus on gender-based violence in Vienna detracted attention from other types of human rights issues, especially abuses associated with the actions of non-state actors like international financial institutions and transnational corporations.")

45. See, e.g., id.

46. See Vienna Declaration and Programme of Action, United Nations World Conference on Human Rights, UN Doc. A/Conf.157/23 (25 June 1993). Statements about women's rights as human rights appear repeatedly in that document. The Declaration states that the United Nations is "Deeply concerned by various forms of discrimination and violence, to which women continue to be exposed all over the world," id., at 3 :

The human rights of women and of the girl-child are an inalienable, integral and indivisible part of universal human rights. The full and equal participation of women in political, civil, economic, social and cultural life, at the national, regional and international levels, and the eradication of all forms of discrimination on grounds of sex are priority objectives of the international community. The human rights of women should form an integral part of the United Nations human rights activities, including the promotion of all human rights instruments relating to women.

See id., at 10, para. 18.

47. See J. Leo, A Near Hijacking at the UN, 119 US News \& World Rep. 32 (1995); D.E. Buss, Robes, Relics, and Rights: The Vatican and the Beijing Conference on Women, 7 Soc. \& Legal Stud. 339 (1998). Human Rights Caucus, Women's Human Rights: A Neglected Part of the Agenda for the United Nations Fourth World Conference on Women (1995), lists as its contact members Charlotte Bunch, Alice Miller of the International Human Rights Law Group and Regan Ralph of Human Rights Watch's Women's Rights Project, laments that "Governments seem to have forgotten that less than two years ago they declared that 'women's rights are human rights.", 
cussed below, then, is what motivated its proponents the documents, the language, the campaigns, and the research programs 'human rights' as a project it generated.

\section{Human Rights as RePRESENTATION}

$[\mathrm{H}]$ ow can the notion that there are rights applicable to women everywhere incorporate the fact of diversity among women? Is it useful to develop international or universal understandings of the position of women? Is human rights law simply the product of the eighteenth century European 'Enlightenment' and inappropriately extended to non-European societies? ${ }^{48}$

I also have in mind another position that crystallized in the academy around 1995. Once Hillary Clinton's speech, an anecdote tailor-made for CNN, is recast as the opening anecdote for an essay on the anthropology of human rights, it demands something like the following commentary:

Human rights is a powerful term. It is the media through which a politics, a particular politics of our time, occurs. It is imperative therefore to understand how the deployment of this term shapes the parameters of debate in a variety of contexts, what can and cannot be recast as a fight for human rights, what effects this recasting has on the causes and constituencies at issue.

This statement is one I would have uttered at conferences circa 1995 and also would have recognized as a position in a debate, as the parameters of a politics of its own. ${ }^{49}$ Circa 1995 , scholars made this claim forcefully and eloquently, ${ }^{50}$ if not without a certain degree of anguish at the concern that in 'exposing the reality' of human rights discourse they might rob causes in which they believed of their most effective weapon ${ }^{51}$ nor without a good dose of self-reflexivity about the situated 'politics' of such a claim itself. This mode of thinking about women's human rights was more readily associated with self-consciously academic feminist law profes-

48. H. Charlesworth, General Introduction, in K.D. Askin \& D.M. Koenig (Eds.), Women and International Human Rights Law xix, at xx-xxi (1999), (citing feminist theorist Rosi Braidotti's claim that feminists must "relinquish the dream of a common language").

49. Cf. A. Riles, Note: Aspiration and Control: International Legal Rhetoric and the Essentialization of Culture, 106 Harv. L. Rev. 723 (1993); K. Engle, International Human Rights and Feminism: When Discourses Meet, 13 Mich. J. Int'1 L. 517 (1992).

50. See, e.g., C. Romany, State Responsibility Goes Private: A Feminist Critique of the Public/Private Distinction in International Human Rights Law, in Cook, supra note 7, at 85.

51. See, e.g., H. Charlesworth, What are 'Women's International Human Rights?', in Cook, supra note 7 , at 58 . 
sors who participated only rarely in UN activities and whose community of peers was feminist scholars in law and other disciplines. ${ }^{52}$

In the classic academic statement on the question, Charlesworth, Chinkin \& Wright ${ }^{53}$ borrow the insights of feminist theory to critique the "abstract rationalism" of international law, but also to insist that there is "no single school of feminism" from which to critique the work of international lawyers in the first place. For this reason, the authors are highly critical of the rights-based framework of human rights. ${ }^{54}$ Referencing a wider feminist and critical legal studies critique, ${ }^{55}$ they note that to focus on human rights is to reduce the complexity of power inequalities to a model in which possessive individualism becomes the goal, in which it is difficult to see rights as in tension with one another or as operating to the benefit of some only to the detriment of others. ${ }^{56}$ In the introduction to a prominent volume on women's human rights, Charlesworth further challenges the very project the volume's contributors espouse. Noting that "It is interesting that there are few doubts expressed about the value of the whole enterprise, unlike, for example, the well-known postmodern skepticism about the use of rights discourse to remedy structural disadvantage," ${ }^{57}$ Charlesworth concludes that "The euphoria sometimes prompted by the vocabulary of human rights may occasionally distract us from the deeply entrenched nature of injustice and the many obstacles to change." ${ }^{58}$ Lest their analysis be read to support those who would derail the progress of women's human rights, however, Charlesworth, Chinkin and Wright

52. Given anthropologists' claims on the reflexive turn to discourse and representation in lawyer's imaginations, see, e.g., J. Clifford \& G. Marcus, Writing Culture (1986), it is interesting that this highly ambivalent focus on human rights as discourse and representation proliferates in the legal literature far more than in the anthropological one. Anthropologists traditionally have served more as foot soldiers for human rights than as its ethnographic observers. See, e.g., American Anthropological Association Executive Board, Statement on Human Rights Submitted to the Commission on Human Rights, United Nations, 49 Am. Anthropologist 1 (1947); American Anthropological Association, Proposed Declaration on Anthropology and Human Rights, in W.E. Davis, American Anthropological Association Memorandum, 23 April 1999.

53. H. Charlesworth, C. Chinkin \& S. Wright, Feminist Approaches to International Law, 85 AJIL 613 (1991).

54. Id., at 634 .

55. Id., at 634, nn. 133 and 134.

56. Id., at $634-637$.

57. Charlesworth, supra note 48 , at xxii.

58. Id., at xxiii. As mentioned earlier, this account takes 1995 as its ethnographic present. Writings since that time seem to devote more energy to the rehabilitation of women's human rights rather than its critique. See, e.g., Otto, supra note 15, at 124 (borrowing 'post-structuralist' methods to demonstrate that both positions in the debate over the universality or cultural specificity of human rights are mutually dependent. She is blunt, however, in her criticism of the activities described in this chapter:

the global women's human rights strategy has had the unintended effect of endorsing the post-Cold War dominance of civil and political rights. Further, although the campaign against gendered violence was designed with careful attention to women's diverse experience of violence, more public effort has been directed towards condemning certain non-Western practices.) 
hasten to add that rights can exude symbolic force and hence become a source of empowerment. ${ }^{59}$

An interest in human rights as representation, then, was an interest in the meaning of human rights, the expression of that meaning in documents and other genres, the limits of such representations, and hence the politics of expression more broadly. Its style of self-presentation was explicitly self-reflexive: drawing on the uses of narrative and autobiographical insight in feminist theory, scholars sought to make their own questions and concerns about rights explicit, and to use these as an engine of theory. In the final section of an article that perhaps epitomizes the discursive critique of women's human rights, ${ }^{60}$ Karen Engle abandons her careful analysis of 'human rights discourse' and recounts, in first person form, her own experience working one summer as a human rights activist and her commitment to feminist and human rights causes. This exercise in self-reflexivity (a revelation of personal experience and the commitments as well as the anxieties it produced) is more than a crude assertion of activist credentials in anticipation of the (mis)reading of one's work by activists as an attack on their enterprise; it is a recounting of the ambivalence that served as the impetus for discursive analysis in the first place. ${ }^{61}$

One of the interesting features of the two genres of rights talk and action I have described is that one could not take both positions - representation and project - at once. Like poles of a magnetic field, they could not be brought together. It may even seem that these two modes are opposites, and their proponents, adversaries. It is as if each genre of rights talk and action was unraveling what the other was weaving. As a case for a new right emerged it was deconstructed; as a new theory emerged, its relevance to the 'real action' was questioned.

Yet in order to disagree, one must first share a register of contention that renders the conflict explicit to oneself and others. Indeed, if the genres of rights talk could not be brought together, in participants' own imagination, the people who took these positions moved very much in the same circles. Almost everyone involved in the campaigns had university affiliations, higher degrees, academic publications. Likewise, almost everyone involved in the circle of scholars with interests in women's human rights was a veteran of feminist and human rights activism of some kind. Both 'sides' were intimately aware of, and concerned about, the response their work was likely to generate with the other. Scholars and activists met at conferences, over e-mail list-servs, and where each crossed over into the other's terrain (the activist took on a visiting lectureship; the law professor held a consultancy at the United Nations) and they addressed one another's views cautiously, amicably, directly or indirectly. In practice, there was no explicit conflict or even contention.

59. Charlesworth, Chinkin \& Wright, supra note 53, at 638.

60. Engle, supra note 49.

61. Id., at 599-606. 
Indeed, whenever a person more accustomed to one register of human rights talk and action crossed over into another, her work became virtually indistinguishable from other work of the same genre. Academics who participated in United Nations programs lobbied for rights, drafted documents, or just kept quiet, but they did not give voice to the critiques they would have mounted of such activities in another setting. A most powerful example of this was the absence of debates about the 'meaning' of terms like 'woman' and 'gender' among government and NGO delegates alike at the Beijing Conference despite the heavy representation of academics at the Conference and parallel NGO Forum. ${ }^{62}$

In her published articles addressed to a more academic audience, for example, Charlotte Bunch makes it clear that she is well-versed in the discursive critiques of her project and that, moreover, she agrees entirely with her critics. She herself is staunchly against "trying to twist women into existing human rights categories, ${ }^{63}$ she points out, and she expounds a far more self-reflexive notion of human rights than some critiques allow: the women's human rights campaign is simply a discursive strategy, a marker for a set of practices, she argues. ${ }^{64}$ She accepts "the challenge to universality" with the claim that she and other proponents of women's human rights are working hard to overcome First World bias, and she demonstrates this fact with citations to poststructuralist feminist theorists of color and from the developing world ${ }^{65}$ Indeed, despite self-positioning to the contrary, it is impossible to find any explicit point of disagreement between the activists and academics working for and around women's human rights during this period. The difference was rather a matter of emphasis, of self-presentation, of where one chose to put one's energies. As mentioned at the outset, what must be explained sociologically, then, is this surprising amount of consensus around the notion that 'women's rights are human rights' at the very moment at which rights emerged as a subject of critique in the academy.

At the outset, we can acknowledge the symbiotic relationship between academics and activists working and writing about women's rights as human rights circa 1995. Each side produced problems or projects the other addressed: the academic critique of the 'universality' of human rights gave activists a new project - networking across national and cultural divides. Likewise, the emergence of women's rights as an issue in human rights law gave feminist scholars a doctrinal hook for their effort to bring feminist and critical race theory to bear on international law. The end points of one kind of analysis served as the beginning points of the other. This was

62. See A. Riles, [Deadlines], in A. Riles (Ed.), Documents: Artifacts of Modern Knowledge (forthcoming).

63. Bunch, supra note 5, at 141.

64. See Bunch \& Frost, supra note 7. This article was written together with an academic who served as a 'consultant' to the CGWL.

65. Bunch, Frost \& Reilly, supra note 42, at 103. 
possible because each side was intimately familiar with the aspirations and activities of the other. One simple conclusion one can draw from this material at this juncture, then, is that the anxious choice scholars and activists were making circa 1995 between promoting and critiquing human rights discourse was always a false one. The one was never tearing down what the other was building. ${ }^{66}$ Yet there is more to it than that.

\section{Rights InSIDE OUT}

What interests me most about projects and representations as genres of human rights work circa 1995 is the shared ambivalence that both modes of engagement produced: at times, those who looked at human rights in the genre of representation stepped back from the abyss and asserted that they too supported projects. Likewise, at times, those who worked with human rights as projects emphasized their own appreciation for the critique of rights and their misgivings about rights as a strategy. One characteristic of the sociality of the women's rights as human rights campaign, in other words, was the way each side momentarily switched positions and looked at the issue from the other point of view.

For both genres, this ambivalence had productive effects. It was as though the foreclosure of one kind of possibility enabled another. Ambivalence about rights was the very impetus for analyses of rights as representation. Likewise, arguably the greatest outcome of the women's human rights campaign - the creation of "several major regional networks" ${ }^{67}$ was the result of the campaign's cosmopolitan leaders' desire to do something about their own ambivalence concerning criticisms of liberal, First World, second feminist bias:

Just as [Chandra] Mohanty argues that a coherent third world feminism can be located despite the multiplicity of locations and identities of third world women, the experience of the women's human rights movement suggests that a global feminism driven by international feminist networking is also possible. Such networking does not require homogeneity of experience or perspective, or even ongoing consensus across a range of issues. ${ }^{68}$

What work does this ambivalence do? Here we must return to some features of projects and representations. In the campaign, as epitomized by Hillary Clinton's speech, human rights work was talk and writing about itself. This 'talk' was not just about (political) action - it was the action: the goal of the campaign, as we saw, was the repetition of a slogan. The words Clinton so forcefully uttered did not 'stand for' an 'issue' rather, they were a set of words to be repeated in diverse contexts, from document

66. Cf. Mol, supra note 18.

67. Bunch, Frost \& Reilly, supra note 42 , at 104.

68. Id., at $105-106$. 
to document. Activists took the adoption of human rights statements as the fulfillment of a goal, an accomplishment, a step forward. At the same time, academics had a theory known as 'discourse' and a method, the study of 'representation,' which sought to analyze human rights action as talk and human rights talk as action. Representation and project were two versions of the same representation.

Projects and representations also shared a common ancestor and enemy - the boxed in, formalistic reasoning that dominated both academic thinking about legal rights on the one hand, and the institutional structures that had defined human rights on the other. For both, the antidote to this categorical thinking was relationality ${ }^{69}$ - an emphasis on loose, complex, multi-layered connections (networking in the mode of projects, or deconstruction in the mode of representation), and a sense that this relationality was the source of their (intellectual or political) power. For an example of this shared fascination with their own relational capacities, consider the statement of the Asia Pacific Forum on Women, Land and Development at the Beijing Conference:

Issues of women's rights are human rights which are universal, indivisible, interdependent and inter-related. They therefore encompass the whole sphere of rights, economic, social and political. No issue of women's rights can be viewed outside of the human rights framework. The Women's Conference in Beijing would, in that context, be a follow-up of women's achievement in Vienna at the World Conference on Human Rights. Let us, therefore, remember that the road for women goes from Nairobi to Beijing, but only through Vienna. ${ }^{70}$

In this statement, women's rights are related to human rights; human rights are related to one another; each UN conference is related to the next. Relationality has emerged in this statement as a fact, an achievement, and a political cause of its own.

What projects and representations shared, in other words, was a particularly late twentieth century way of analyzing problems, of which a 'gender perspective' is perhaps the pinnacle achievement. ${ }^{71}$ They shared, for example, a notion of the multiplicity of perspectives on the meaning of human rights. Indeed, it was this perspectivism that had enabled the critical gendered analysis of the old Cold War human rights paradigm in the first place: the activist's campaign to expand and transform the category of human rights was the outcome of a particular kind of academic analysis - a critique of what is taken as self-evident, a demonstration that surfaces are different from underlying realities.

69. Cf. M. Strathern, The Relation: Issues in Complexity and Scale, 6 Prickly Pear Pamphlet (1995).

70. Asia Pacific Forum on Women, Law and Development, Statement for the 39th Session of the Commission on the Status of Women, 15 March-4 April 1995.

71. The innovation of the term 'gender' over 'sex' was precisely to draw attention to the sociality constructed relations between men and women rather than the innate qualities of men or women. $C f$. Strathern, supra note 69. 
Ambivalence, then, was the engine of common progress, the rejection of opposites in favor of a third indeterminate, even indefinable way. From this perspective, I believe we can read the 'women's rights are human rights' campaign and its critique - the deployment and the deconstruction of 'rights' as 'rights talk' - as a chapter in the twentieth century excess of representation. Here is what I mean by an excess of representation: unlike political activism around torture, for example, where the problem is the undescribable, unspeakable nature of the harm, ${ }^{72}$ the harms to women that activists sought to associate with human rights were already too easily represented - they were the mundane, casually talked about harms: the daily incidents of food shortages, domestic violence or being passed over for a promotion. The problem for activism was that this very over-representation seemed to numb the activist's audience to the harm itself. Yet to solve this problem of over-representation by turning to further 'rights talk' and critiques was to add more layers, more of the same.

What was unique about this particular academic-activist relationship, then, was that both groups shared a common problem. Of course they shared a sense of being on a common periphery from the human rights and United Nations establishment. ${ }^{73}$ Yet there was something more: once unleashed, representations and perspectives proliferate beyond their framers' control. As we saw, the singular stumbling block for the women's human rights campaign was not so much the intransigence of the international community as the divisions within the global feminist community. As the leaders of the campaign repeatedly insisted, women's human rights was selected as the ultimate goal precisely because, in the aftermath of the bitter conflicts over the dominance of First World agendas of the 1970s and 1980s, human rights was believed to be less contentious than other agendas. Likewise, the reflexive turn in the study of rights, and the critique of rights as representation was a response to similar divisions within the academy - in particular to the emergence of a 'Third World' critique of academic international law.

Yet as we saw the ambivalence and self-reflexivity that dominated discussions of women's human rights during this period - the outcome, I have suggested, of a particular epistemological moment, an awareness of the indeterminacy of things, the multiplicity of possible perspectives - engendered a need to see things from others' point of view. In a recent study of the emergence of a medical specialty in pain therapy in France, Isabelle Baszanger ${ }^{74}$ argues that the division of the community of specialists into two camps who follow different theories and practices and seemingly have little to do with one another at the very moment at which the new spe-

72. See E. Scarry, The Body in Pain: The Making and Unmaking of the World (1985).

73. See Engle, supra note 49, at 519 ("Women's rights discourse is generally positioned at the periphery of human rights discourse, both challenging and defending the dominant human rights model as it attempts to fit causes into that model.").

74. See I. Baszanger, Pain Physicians: All Alike, All Different, in Berg \& Mol, supra note 18, at 119 . 
cialty emerges and fights for respectability with the medical profession must be understood as an act of self-constitution centered in the

dual manner in which all actors involved treat a vital resource [the scientific theory of pain] even though this group is structured around internal differences gradually fashioned into practice, this theory, acting as a 'boundary object' between different groups, is the source of its stability. ${ }^{75}$

Her point is that it is the internal division which allows pain, as a theory and a set of professional practices, to take form.

In a similar way, the emergence of a virtual sociality of 'groups' of activists then responded to a concrete political problem. The turn to rights, and in particular to rights talk (projects, representations) momentarily, anxiously, ambivalently resolved what was acknowledged as ultimately unresolvable only by drawing that conflict into a debate among virtual groups and their virtually opposed projects and representations. Rights served as a marker, an empty box around which a more contentious conversation could be cautiously continued.

My claim is that the shared ambivalence generated the effect of two groups, activists and academics, where what was really at stake was two modes of engagement - representation and project. To imagine another register for doing what one does (talking about rights) is to imagine an outside vis-à-vis oneself. For participants in rights talk, then, project and representation worked as inside out views of the same device - each an 'inside speak' versus an 'outside speak' to the other. A preliminary conclusion one can draw from this short ethnographic sketch, then, concerns the sociology of 'groups' such as academics and activists: what these two 'groups' might have to do with each other is an impossible question, I wish to contend - for participants as much as for outside analysts - because the groups are not 'real' entities but rather simulations produced by the discursive phenomenon of rights. The sociology cannot be described, in other words, other than in the language of rights.

This leads to a final question: why rights? Why do rights emerge as the source of a flurry of deconstructive, self-reflexive endeavors on the one hand and of networking projects on the other circa 1995? Here, drawing on the previous analysis, I can only offer my own conjecture: what is interesting about 'human rights' is that they can alternatively be conceived as tools - means to other ends such as women's empowerment - and as real entities, ontologically distinct from and prior to any political claims or strategies one might have or analyses one might make. They encourage the kind of double view that, in the case of projects and representations, fueled the virtual sociality I have described. Academics have tended to fixate on one possibility entailed in this dual perspective or the other - either to show how the 'real' issues serve as the focal point for a

75. Id., at 120 . 
new transnational sociality, ${ }^{76}$ or to demonstrate that human rights are in fact nothing more than a set of rhetorical strategies. ${ }^{77}$ I find knowledge professionals' movement between these alternatives more interesting and challenging to apprehend.

Here we should look to what activists and academics alike explicitly say about the pull of rights. They are drawn to rights not because of their inherent significance, they insist, but because others value them. Consider for example the confusion about the meaning of 'women's rights are human rights' I routinely heard among the women's organizations among whom I conducted ethnographic research in Fiji. For Fiji's women's rights professionals I knew, 'human rights' were part of the global agenda, and hence to be included in their list of stated commitments if they wished to signal their status as transnational actors. ${ }^{78}$ Women's rights as human rights evoked UN processes and documents, as when a newsletter simply reprinted under the topic of women's human rights, the portions of the Vienna document that referred to women's rights. ${ }^{79}$ Yet rarely did activists describe events in Fiji as 'human rights violations.' Rather, human rights conjured up images of violations elsewhere - female infanticide in China or female genital mutilation in Africa being two common examples.

Rights in other words index the outside, the other - others' interest in rights, violations of rights elsewhere. One dimension of the outside here is the law. Rights of course are 'legal' entities - they generally are acknowledged to be among the subjects that lawyers and legal scholars should be concerned about. For both feminist legal scholars and activists circa 1995, lawyers proximate outsiders to their own circle. For human rights activists, the legality of rights located their projects beyond their own activities, in the realm of the established, the settled, the mainstream. ${ }^{80}$ The same could be said for feminist and deconstructivist legal scholars. The cartoon-like simplicity of rights, compared in both projects and representations, then, might be understood as evoking this otherness of law.

76. See, e.g., Keck \& Sikkink, supra note 12.

77. See, e.g., Engle, supra note 49.

78. See, e.g., E.H. Boyle \& J. Meyer, Modern Law as a Secularized and Global Model: Implications for the Sociology of Law, in Y. Dezalay \& B. Garth (Eds.), Global Prescriptions: The Production, Exportation, and Importation of a New Legal Orthodoxy (2002) (to be published).

79. See, e.g., B.R. Ganilau, The Road to Beijing, S'Pacifically Speaking: Newsletter of the PNGOCG, May 1995.

80. Interestingly, the phrase of 'legal rights' had far more appeal with activists in Fiji than 'human rights' and was often used in the very contexts the global women's organizations hoped to deploy the notion of human rights such as violence against women and married women's citizenship rights. Women's groups also sought to associate these issues with the more gender-neutral theme of 'development.' See, e.g., I.P. Jalal, Law for Pacific Women: A Legal Rights Handbook (1998); Cf. Fiji Women's Rights Movement, Putting an End to the Crisis, Balance, November-December 1995; Fiji Women's Rights Movement, Drafting Bill on Domestic Violence, Balance, May-June 1995; L. Prakash, Crime Against Women, Balance, December 1994. 
It is the simplicity of something viewed from afar, something imagined to be others' commitment.

In this sense, for both the producers of representations and of projects, making 'rights' the focal point takes the project outside, beyond their own inner circle. We might say that it helps to turn their commitments and activities inside out ${ }^{81}$ and hence to make those projects and representations real to themselves. The 'beyond' quality of rights generates a sense of an outside, an audience of lawyers, of UN Diplomats, for example, for whom rights - and hence one's representations of them - might 'mean something.' The deployment of 'rights,' whether as a matter of projects or representation, then is the virtual experience of 'our group' as apart from 'theirs,' of one's own community and the 'mainstream,' or the 'Third World,' or the 'First World,' or the 'academy.' I would venture that this is the inherent appeal of legality and hence of rights: as a marker of others' commitments, rights signal to imagined outsiders the fruits of one's labor, and hence virtually establish one's social existence as apart from those imagined as beyond.

81. See Riles, supra note 2. 
Reproduced with permission of the copyright owner. Further reproduction prohibited without permission. 